\title{
THE REGULATION OF INTERCOUNTRY ADOPTION IN SOUTH AFRICA
}

A major child-welfare challenge presently facing South Africa is the securing of permanent placement for the increasing number of its abandoned and vulnerable children (Art 27 of the Convention on the Rights of the Child 1577 UNTS 3 (the CRC); Article 256 Hague Convention 187 CTS 227; African Charter on the Rights and Welfare of the Child CAB/LEG/24.9/49 (1990) (the ACRWR) and $s 28$ of The Constitution of the Republic of South Africa, 1996). Factors such as HIV/AIDS; poverty; neglect; exploitation; constraints on the availability of housing in urban areas (during the State of the Nation Address 2013, the President noted the problems facing many South Africans, but failed to provide any solution to resolve these issues); lack of access to services assisting in the maintenance of families; illegal immigration; child abandonment and other traumatic experiences (an example hereof is the violence against children experienced in South Africa), all contribute to the current position of many children in Africa, and in South Africa specifically. Despite communities doing the best they can to care for such vulnerable children, providing appropriate care remains a challenge (a UNICEF audit identified 400 voluntary organizations providing care for some 190000 children). The devastating and long-term effects on the family as the primary unit of care of a child, where one or both parents have died, cannot be underestimated. Traditionally in South Africa, where a child is deprived of his or her parent or parents, the child was cared for by the grandparents (specifically the grandmother), and other family members (Roby "Children in Informal Alternative Care. Discussion Paper" 2011 http://www.bettercarenetwork.org/BCN/details.asp?id=25477\&themelD $=100$ $2 \&$ topicID=1013Ab (accessed on 2016-02-20) fn 7). The breakdown of these traditional mechanisms of support for children has contributed substantially to the plight of children that had been left orphaned and abandoned. Over the years, this support by the extended family and the community played a pivotal role in providing alternative care for orphaned children. However, increasing adult mortality as a consequence of specifically HIV/AIDS, has obliterated a large portion of the community who were acting as care-givers, and with it, the impact on the feasibility of this form of care is evident. South Africa experiences the highest rate of HIV/AIDS in the world, and many children have lost one or both parents to the disease. In 2010 an estimated 3,7 million children were orphaned in South Africa, approximately 50 per cent from HIV/AIDS. Since 2012, there were an estimated 53 million orphaned children on the African continent African Children Forum ("Intercountry Adoption of Children in Africa" http://www.africanchildforum. org/site/index.php/programmes/the-african-child-law-programme/intercountry -adoption-of-children-in-africa.html (accessed on 2015-04-02)). This can be attributed to the HIV/AIDS epidemic which is prevalent on the continent, and further to war, famine and lack of education. The United States has been linked to approximately half of the world's total number of international adoptions (see Bartholet "International Adoption: A Way Forward" 2010- 
201155 New York Law School LR 687 689). In a report produced by the African Child Policy Forum it was observed that South Africa had the second highest number of intercountry adoptions on the African continent during the period 2004-2010, with a recorded 1583 cases (Coetzer "Concern Over Intercountry Adoption: Between 2003 and 2011, At Least 41000 Children from Africa were Sent Abroad for Adoption" 2016-06-26 http://www.lea dershiponline.co.za/articles/concern-over-inter-country-adoption-1691.html (accessed on 2015-05-05)). The extremely rapid rate of orphanhood and destitution among children makes it difficult for families and communities to respond in the traditional manner of taking these children into extended families. The situation has led to the emergence of a new form of family structure: a household headed by one of the affected children, or simply a child-headed household $(\mathrm{CHH})$ (Report on Research Conducted by The University of South Africa; A Situational Analysis of Child-HeadedHouseholds in South Africa Unit of Social Behaviour Studies: HIV/AIDS and Health Bureau of Market Research (2008) 17). UNICEF reported as early as 2010, that approximately 150,000 children were believed to be living in CHHs (UNICEF South Africa Protection for Orphans and Vulnerable Children $2010 \mathrm{http}: / / \mathrm{www}$.uncef org (accessed 09-06-2016)). Like many African countries, South Africa is faced with the challenge of an increasing number of orphans and children who are considered vulnerable. (See page 6 of UNICEF Africa's Orphaned Generations states that in 2001 over 11 million children who live in Sub-Saharan Africa have lost one or both parents to HIV/AIDS. This number rose to 20 million in 2010).

With the commencement of the constitutional era in South Africa, it became apparent that the Child Care Act (CCA) fell short of certain constitutional provisions, and several articles contained in relevant international conventions, which were ratified by South Africa, were not assimilated into the provisions of national legislation. Following the judgment of the Cape High Court in the Minister for Welfare and Population $v$ Fitzpatrick, (2000 (3) SA 422 (CC)), all restrictions on intercountry adoption were eliminated. The court held that the provisions of section $18(4)(f)$ were "too blunt and all-embracing" (par 20) and, consequently they provide that under no circumstances may a child who is born to a South African citizen, be considered for adoption by non-South African citizens. As such, section $18(4)(f)$ did not give paramountcy to the best interests of children. This is clearly inconsistent with the provisions of section 28(2) of the Constitution, and no limitation could potentially be considered justifiable under the Constitution. Hence the provision under consideration is invalid. The judgment led to a vacuum in South Africa's national legislation, and such adoptions remained unregulated, placing the interests of the children at risk. Acting upon the recommendations made by the Law Commission, South Africa ratified and became a state party to the Hague Convention some three years after the judgment in Fitzpatrick. The urgency of the need to promulgate national legislation to provide for the regulation of intercountry adoption became apparent in the widely publicized decision of the judgment of the High Court in De Gree ((2007) SCA 87). Schäfer refers to this judgment as a "shameful episode in South Africa's law". After the Fitzpatrick judgment had been handed down, it took 10 years to promulgate national 
legislation providing for and regulating intercountry adoption (Children's Act 38 of 2005).

In line with the present-day international human rights approach, the provisions of ratified international conventions reinforce the principle that every child has the "right to family life or appropriate alternative care". In light hereof, it is clear that the current International-law approach to the placement of vulnerable children includes the consideration of intercountry adoption as a potential and effective solution. With the enactment of the interim Constitution (Act 200 of 1993) and final Constitution (then Act 108 of 1996), the rights of a child to protection and care became constitutionally entrenched in South Africa. It is apparent that the security and stability in the life of any child is of fundamental importance in the Constitution. The vehicle for change in child law in South Africa was the Children's Act 38 of 2005 (hereinafter referred to as the "CA"). Critics have suggested that the Act ought to have done more in reforming the Children's Court (Schäfer Child Law in South Africa: Domestic and International Perspectives (2011) 59). Whether the Children's Court should be granted such jurisdiction or not has been considered in two instances in the Constitutional Court to date. In both cases the Court found that the provision is correct (Minister of Welfare and Population Development v Fitzpatrick 2000 (3) SA 422 (CC); AD v DW 2008 (3) SA 183 (CC)). Although the Act has retained the jurisdiction of the High Court in considerations of matters relating to guardianship, adoption matters continue to be determined in the Children's Courts. The CA acknowledges the need to give effect to the provisions and spirit of the Geneva Declaration on the Rights of the Child, the CRC, the ACRWC and the Universal Declaration of Human Rights, as well as the provisions in the relevant statutes and instruments of specialized agencies and international organizations that are concerned with the welfare of children by securing permanent placement. The CA provides that, for the full and harmonious development of the child's personality, a child should grow up in a family environment in an atmosphere of happiness, love and understanding. The Act accordingly signifies a heightened awareness of the authority of the child as a bearer of rights, and most importantly, the consideration of a child's best interests as paramount in all decisions relating to the child (s 2(b)(iv)). In all cases, including the consideration of intercountry adoption, the guiding principle remains that what serves the "best interests" of the child. Like the Hague Convention, the CA does not expressly promote or encourage intercountry adoption, but focuses rather on the regulation of the process of intercountry adoption, making all attempts to eliminate the potential of the abusive practices experienced in the past. In order to do so, provision is made for the cooperation and communication between relevant authorities (Bainham "Interim Care Orders: Is the Bar Set too Low? 'The Implementation of Care Plans, and Its Relationship to Children's Welfare'" 2003 CFLQ 71 230). Through this, intercountry adoption was legalized as an alternative placement for the many vulnerable children in South Africa (Mezmur "Intercountry Adoption as a Measure of Last Resort in Africa: Advancing the Rights of a Child rather than a Right to a Child" 2009 International Journal of Human Rights 4). Regulations to the Act were 
adopted in April 2010. These Regulations elaborated on the provisions of the $\mathrm{CA}$, and when read in combination, it is apparent that they seek to regulate the practice of intercountry adoption and to provide for, and ensure, the protection of children in a manner that is equivalent to the principles and standards set by international and regional instruments.

The security and stability in the life of any child are the primary aims of the Constitution. When the CA incorporated the provisions of The Hague Convention, the existing scope of alternative permanent-placement options needed to be expanded in national legislation to achieve this aim. This was necessary as the relevant rights in the Hague Convention far surpassed the recognized forms of alternative permanent placement in the existing legislation. The Act also makes provision for new developments and mechanisms to change the practice of adoption in South Africa, and to expand the possibilities for adoption domestically (Nielsen and Mezmur "Surveying the Research Landscape to Promote Children's Legal Rights in an African Context" 2007 7(2) AHRLJ 330). This was achieved through marketing and a number of national and provincial public-awareness campaigns. Currently in South Africa, the number of children placed in foster care has increased significantly. This may be partly as a result of legalization of foster care by extended family members (In 2000, 200,000 South African children were in court-ordered foster care. By 2014, 553,000 children were in foster care, with an extensive backlog). It is also noted that many vulnerable children are being placed in institutional care. Three hundred and forty-five children's homes are registered in South Africa, and cater for 21,000 children (UNICEF "Protection for Orphans and Vulnerable Children" 2010 www.unicef.org/southafrica/protection_6633.html (accessed 2016-02-20)). In contrast, national adoption is on the decline. South Africa experienced 1,522 national adoptions per annum (2013-2014) and 177 intercountry adoptions (2013-2014). In 2014-2015, 1,401 national adoptions and 250 intercountry adoptions were finalized. In an attempt to increase this number, the Department of Social Development, in partnership with the various relevant stakeholders, was urged to promote adoption services.

The Constitution makes provision that every child has the right to "family care or parental care or to appropriate alternative care" (s 28(1)(b)). The Explanatory Memorandum to the CA confirmed a child's constitutional right to adoptive care. This provision is in line with that of the CRC (Art 20), ACRWC and Hague Convention which provide that a child in need of care shall be entitled to special protection from the State, and such protection shall include foster placement and adoption. Section 28 of the South African Constitution provides an important benchmark in the protection of children in South Africa. Provisions to this effect appear in the Preamble to the CA, further stating that the State has an obligation to respect, protect, promote and fulfil such rights. The Act supplements any rights that a child has in terms of the Bill of Rights. The Preamble to the Act makes it clear that in determining whether intercountry adoption should take place, the decision must always be based on a determination as to what is in the best interests of the child concerned. The Act provides that, in protecting and promoting the rights of the child, it is neither desirable nor possible to do so in isolation of the improvement in the lives of the community, nor in isolation from their families and communities. The CRC and the Constitution reinforce the 
principle that every child has the right to family life or to appropriate alternative care, making the consideration of intercountry adoption after the ratification of the Hague Convention, and promulgation of the Act in 2005, a potential solution for these children. In 2005, the CA was enacted to govern the laws relating to the care, contact and the protection of children. Besides defining the parental responsibilities and rights, the CA also makes provision for the establishment of Children's Courts and the appointment of social workers and child-care experts. The CA further provides for the regulation and establishment of places of safety and orphanages, ensures the rights of orphans, and regulates instances of adoption. It has a much broader scope than its predecessors in its application to children's rights, as well as providing in particular the much-needed and long-overdue redrafting of adoption law.

Although the legal effect of an adoption order in the Act remains the same as that in the 1983 Act, major changes were effected to the existing legislation regarding the process of adoption. More efficient procedures for the management of adoption were, for instance, provided. These procedures include the establishment of a register for adoptable children and prospective adoptive parents (RACAP). Keeping the register has proved to be a valuable approach in making a determination that is in the best interests of the child to consider a placement abroad. Through the keeping of a register, an integrated approach is created to the screening and matching of adoptable children and prospective adoptive parents. Once a child has been assessed by the social worker and deemed to be adoptable, his or her identifying information is entered into the register. Once the child has been adopted, all information about it is removed from the register; consequently those names remaining indicate that the child so listed, is adoptable. On application by the social worker to the Director-General, a person who has been assessed to be an eligible prospective adoptive parent can have his or her name placed on the register. This register is probably the single most important innovation of the Act. The stability of the family unit as a means of the optimal care for a child is not disputed in national legislation or international instruments, and, the opportunity for a permanent, life-long relationship cannot be underestimated. Section 254 of the Act in particular underscores the legislature's intent to mirror the aims of the Hague Convention. When making a determination on the placement of an abandoned, neglected, abused or orphaned child, the "best interests" of such child is deemed of paramount importance, and this criterion outweighs any other consideration. Determining a child's "best interests" includes the child's right to security, need for affection, and continuing and long-term stability. It is recognized that these factors should be the basis for any adoption plan. Considering that the child's interest is deemed of paramount importance in terms of the Constitution, Justice Cameron held in Centre for Child Law v Minister of Justice and Constitutional Development, that the meaning of "paramount" entails that:

"The child's interests are more important than anything else, but do not mean that everything else is unimportant. The paramount principle does, however, require a truly child-centred approach, which in turn requires a close and individualised examination of the precise real life situation of the particular child involved" (Centre for Child Law v Minister for Justice and Constitutional Development and Others (CCT98/08) [2009] ZACC 18 17). 
This entails that, when determining the child's best interests, the courts must evaluate each individual case or situation in the light of the individual child's position and the effect that the situation is having, or will probably have, on the individual child. It is accepted, however, that given the diversity of cultures within South Africa, perceptions of social standards and of what is deemed acceptable to a particular community, may vary from time to time. The South African Constitution recognizes this diversity, and the Constitutional Court has repeatedly held that our constitutional values include tolerance of and respect for such diversity. The diversity in itself demands a contextualized approach to what is considered to be in the best interests of the child in the community concerned. The religion and culture of the community in which the child is growing up, is important and must be taken into account.

Against the background of the constitutional challenges arising from the provisions of the CCA, the Act of 2005 takes an inclusive approach as to who may adopt a child. The Act provides that the Children's Court "shall have regard" to factors set out in the Act. In South Africa, the hesitancy to adopt a child by the majority of the population is disconcerting. A number of factors impact the reluctance to adopt a child, including cultural and economic considerations. Schäfer amongst others states that adoption is underutilized in South Africa as a means of providing care (Skelton and Carnelley Family Law in South Africa (2010) 284). This is particularly evident when comparing adoption to foster care (South African Law Commission Project 110 http://www.justice.gov.za/salrc /reports/r_pr110_01_2002dec.pdf (accessed 2016-02-20) par 18.2; Schäfer Child Law in South Africa: Domestic and International Perspectives 284, indicate that 5,217 adoptions and 1,003 intercountry-adoption orders were finalized between 2008 and 2009). The stability and permanence offered by adoption are important aspects of a comprehensive child-care and protection programme, and it is generally accepted to be the best option where a young child has been abandoned or orphaned. However, each case is determined on an ad hoc basis on consideration of the best interests of the child. Certain critics argue that the cultural and community diversity of the child and prospective adoptive parent or parents, must be taken into consideration when determining if the "matching" is suitable. The single most important requirement when considering adoption is that the proposed adoption should serve the interests of the child and be conducive to the welfare of such child. Davel opines that this consideration is ultimately the deciding factor and is to be measured by all factors that will affect the future of the child, and is not restricted only to financial and physical comforts. The application of the principle of a child's best interests was considered by the Constitutional Court in $A D \vee D W$. The case concerned an application for adoption of a baby girl. An important aspect of the decision of the Court was the Court's express confirmation that the best interest of a child in this case was best protected by following the correct judicial procedures when bringing adoption applications. Another important finding of the Court was regarding the relationship between the principle of subsidiarity as applied in intercountry adoptions and the best interest principle. The Court made it clear that the subsidiarity principle was subsidiary to the best interest principle. Similarly, 
in $S \vee M$ the Court held that it was essential to take a child-centered approach when determining the best interests of the child.

The Act makes express provision for the fact that a person may not be disqualified from eligibility to adopt on the basis of their financial status. In lieu thereof, the Act provides that any person who wishes to adopt a child "may apply for a means-tested social assistance where applicable". With regard to State financial aid, the Government of South Africa pays child support to care-givers in need. These grants are regulated by the Social Assistance Act 2004. The means test sets the income of the applicant at R3300.00 per month for single care and R860.00 per month for married couples (Statistics of children in South Africa's Children Court Abantwana Babalulekile October 2015). In terms of the provisions of this Act, the person or persons receiving such grants must be South African citizens, permanent residents or refugees currently living in South Africa. As a general rule, eligibility for such a grant is determined in terms of a means-test. This is not true for foster-care grants, unless the child concerned is the recipient of some form of income. Poverty-stricken family members of the child are compelled financially to keep the child of a family member in foster care. A State grant of R860.00 per month is presently received, and currently 533,000 recipients benefit from this grant. No application for State assistance can be made where a child is adopted. On 24 February 2016, Finance Minister Pravin Gordhan announced increases for the five social grants presently funded by the South African Government (Ferreira Fact Sheets and Guides Social Grants in South Africa - Separating Myth from Reality). Of concern is the fact that the number of social-grant recipients has increased significantly over the past two decades (Ferreira states that an estimated 4-million persons received social grants in South Africa in 1994 and 16.9-million recipients are paid as of 30 September 2015). Concern has been raised as to whether these large numbers of recipients can be sustained in the long term by the Government. Not only has South Africa seen no decrease in social spending, grant amounts have increased, and the ages of those who qualify to receive such grants have been extended by the DSD to 23 years of age. This is based on the alarming number of childheaded households in South Africa. Ferreira reported that the South African public finance is under strain, and the then Minister of Finance, Nhlanhla Nene, warned of the need to "tighten the country's financial belt". A potential solution for appropriate alternative placement of South Africa's many vulnerable children requires some serious consideration, inter alia intercountry adoption. The purpose of intercountry adoption is to provide children deprived of families with permanence and security. In South Africa, intercountry adoption is governed by Chapter 16 and schedule 1 of the CA. While schedule 1 contains the text of the Hague Convention, Chapter 16 contains the provisions concerning the process of intercountry adoption in South Africa. In essence, the CA gives effect to the provisions of the Hague Convention by providing for the recognition of certain foreign adoptions, determining by means of facilitation who is a fit and proper adoptive parent for an adoptable child, and finally, to generally regulate intercountry adoption (s 254). Before a State of origin (the "sending" state) can consider an application for intercountry adoption, the competent authorities of the State must establish the following: 
1) That the child in question is adoptable (Art 4(a)).

2) That there is no possibility of adoption or placement nationally (Art 4(b)).

3) That intercountry adoption is in the best interests of the child (s 230).

The CA recognizes four categories of intercountry adoption, namely:

1) Adoption of children from South Africa by a person in a Convention country (s 261).

2) Adoption of children from South Africa by a person of a non-Convention country (s 262).

3) Adoption of children from a Convention country by a person within South Africa (s 264).

4) Adoption of children from a non-Convention country by a person in South Africa (s 265).

The CA makes provision that the principle of subsidiarity is mandatory, in that domestic measures to place a child are prioritized before a placement is sought for the child in terms of intercountry adoption. The CA states that the name of the child should be placed in the RACAP for at least 60 days to determine if no fit and proper adoptive parent for the child is available in the Republic.

Article 6 of the Hague Convention mandates Contracting States to appoint a Central Authority (as defined in S 257(1) of the CA) to carry out the duties prescribed by the Convention. This is equally applicable to States that are not Contracting States to the Hague Convention. Article 6 of the Hague Convention provides in this regard as follows:

"[a] Contracting State shall designate a Central Authority to discharge the duties which are imposed by the Convention upon such authorities."

While the Convention does not define the term Central Authority, the CA includes a definition as follows:

1) A Central Authority in relation to South Africa means the Director General.

2) In relation to a Convention country, it means a person or office designated by such country under Article 6 of the Convention (s 257).

In South Africa, the Director General of the DSD appoints the Central Authority. Applications for intercountry adoption are made to the Central Authority. The aim is to protect the best interests of children involved in the process of intercountry adoption. This task is of paramount importance. The Central Authority is also tasked with maintaining relationships and promoting cooperation among the competent authorities within the State to protect children and to achieve the objectives of the Convention. In addition, where an adoption takes place after the child has been transferred to the receiving State and the Central Authority of the receiving State is of the view that the continued placement of the child with the prospective adoptive parents is not in the best interests of the child, the Central Authority is required to take the necessary measures to protect such child. These measures include withdrawing the child from the prospective adoptive parents and arranging 
temporary care and a new placement for the child in consultation with the Central Authority of the State of origin. The Central Authority therefore acts as a "gatekeeper", with all adoptions in-and-out of the country channelled through its checks. It fulfils an important function to eliminate practices which may violate the best interests of the child.

\section{Conclusion}

The argument raised in the CRC in the past against intercountry adoption was largely due to the dispersed and unregulated intercountry-adoption system. This concern, however, has been addressed by the Hague Convention. Consequently, the potential of a child being granted a permanent placement abroad has become more palatable.

When certain legislative provisions are considered, however, the question must be raised whether further barriers have been created by the legislature when seeking placement for a child in a permanent family (Bartholet "International Adoption: Current Status and Future Prospects. The Future of Children" 19933 Spring 95). The Act clearly established who was eligible to adopt, but these provisions were not supported by any policy document outside the norms and standards which could provide guidance to organizations in respect to adoption criteria, which include inter alia age and size of family. Until recently, South African adoption organizations could establish their own policies and criteria regarding what they considered established a good adoption practice in line with their own value system, as long as no law, constitutional or otherwise, was infringed thereby.

Concerning the hierarchy of alternative placement of a child, the South African Central Agency and accredited organizations were operating in unchartered waters. These agencies noted, with concern, the need to have a uniform set of principles, regulations and guidelines that could be followed in making such determinations. No uniformity in the approach of the relevant stake holders existed. With and by the enactment of the CA, and as such the incorporation of the provisions of the Hague Convention, these concerns have been addressed.

Glynis van der Walt Nelson Mandela Metropolitan University, Port Elizabeth 